\title{
Effects of salinity on the treatment of synthetic petroleum-industry wastewater in pilot vertical flow constructed wetlands under simulated hot arid climatic conditions
}

\author{
Thomas V. Wagner ${ }^{1,2}$ (D) Fatma Al-Manji ${ }^{1} \cdot$ Jie Xue $^{1} \cdot$ Koen Wetser $^{1} \cdot$ Vinnie de Wilde $^{1} \cdot$ John R. Parsons $^{2} \cdot$ \\ Huub H. M. Rijnaarts ${ }^{1}$ - Alette A. M. Langenhoff ${ }^{1}$
}

Received: 24 April 2020 / Accepted: 20 August 2020 / Published online: 1 September 2020

(C) The Author(s) 2020

\begin{abstract}
Petroleum-industry wastewater (PI-WW) is a potential source of water that can be reused in areas suffering from water stress. This water contains various fractions that need to be removed before reuse, such as light hydrocarbons, heavy metals and conditioning chemicals. Constructed wetlands (CWs) can remove these fractions, but the range of PI-WW salinities that can be treated in CWs and the influence of an increasing salinity on the CW removal efficiency for abovementioned fractions is unknown. Therefore, the impact of an increasing salinity on the removal of conditioning chemicals benzotriazole, aromatic hydrocarbon benzoic acid, and heavy metal zinc in lab-scale unplanted and Phragmites australis and Typha latifolia planted vertical-flow CWs was tested in the present study. $P$. australis was less sensitive than T. latifolia to increasing salinities and survived with a NaCl concentration of $12 \mathrm{~g} / \mathrm{L}$. The decay of T. latifolia was accompanied by a decrease in the removal efficiency for benzotriazole and benzoic acid, indicating that living vegetation enhanced the removal of these chemicals. Increased salinities resulted in the leaching of zinc from the planted CWs, probably as a result of active plant defence mechanisms against salt shocks that solubilized zinc. Plant growth also resulted in substantial evapotranspiration, leading to an increased salinity of the $\mathrm{CW}$ treated effluent. A too high salinity limits the reuse of the $\mathrm{CW}$ treated water. Therefore, $\mathrm{CW}$ treatment should be followed by desalination technologies to obtain salinities suitable for reuse. In this technology train, CWs enhance the efficiency of physicochemical desalination technologies by removing organics that induce membrane fouling. Hence, $P$. australis planted CWs are a suitable option for the treatment of water with a salinity below $12 \mathrm{~g} / \mathrm{L}$ before further treatment or direct reuse in water scarce areas worldwide, where CWs may also boost the local biodiversity.
\end{abstract}

Keywords Benzotriazole $\cdot$ Benzoic acid $\cdot$ Zinc $\cdot$ Phragmites australis $\cdot$ Typha latifolia $\cdot$ Vertical flow constructed wetlands

\section{Highlights}

- Constructed wetlands remove conditioning chemicals from saline water

- An increase in salinity lowers the benzotriazole and benzoic acid removal

- Salinity shocks result in the release of zinc from planted constructed wetlands

- Evapotranspiration increases electrical conductivity which limits the reuse of water

Responsible Editor: Alexandros Stefanakis

Electronic supplementary material The online version of this article (https://doi.org/10.1007/s11356-020-10584-8) contains supplementary material, which is available to authorized users.

Thomas V. Wagner

thomas.wagner@wur.nl

1 Department of Environmental Technology, Wageningen University \& Research, P. O. Box 17, 6700 EV Wageningen, The Netherlands
2 Institute for Biodiversity and Ecosystem Dynamics (IBED), University of Amsterdam, P. O. Box 94248, 1092 GE Amsterdam, The Netherlands 


\section{Introduction}

Oil extraction generally results in the production of extensive volumes of petroleum industry wastewater (PI-WW) that contains heavy oil fractions and light hydrocarbons (Fakhru'l-Razi et al. 2009). Heavy oil fractions are commonly separated from PI-WW aboveground in oil/water separators (Murray-Gulde et al. 2003). The remaining water contains light hydrocarbons, heavy metals, salts, and conditioning chemicals, such as corrosion inhibitors and antiscalants (Fakhru'l-Razi et al. 2009; Rehman et al. 2018; Afzal et al. 2019), and its specific composition depends on the characteristics of the oil reservoir and the conditioning chemicals that were used in the oil extraction process (Ozgun et al. 2013). After the oil/water separation, there are different options for further management of PI-WW: injection back into the subsurface formation where the oil was extracted from, discharge aboveground, or reuse in the oil extraction process (Fakhru'l-Razi et al. 2009). However, since oil extraction often occurs in water-scarce locations, such as the Arabian peninsula, it is beneficial to treat and reuse the PI-WW instead of disposing of it to enhance the local water supply. In areas with sufficient water supply, the treatment and reuse, instead of disposal of PI-WW, protects the environmental quality of surface water and prevents the contamination of groundwater that is potentially used as a drinking water source. Various physical, chemical, and biological treatment technologies for PI-WW that could allow its reuse have been studied in recent years (Fakhru'l-Razi et al. 2009; Sosa-Fernandez et al. 2018, 2019; Sudmalis et al. 2018). Amongst these, naturebased treatment in the form of a constructed wetland $(\mathrm{CW})$ is an attractive treatment option, because it has low energy and maintenance requirements, it is regarded as aesthetically enriching landscapes, and it can function as an oasis in desert landscapes where it can significantly improve the local biodiversity (Stefanakis 2018, 2019, 2020a).

CWs are man-made wetland systems in which various natural processes remove contaminants from a water stream, such as adsorption, biodegradation, photodegradation, and plant uptake (Garcia et al. 2010; Wagner et al. 2018; Hashmat et al. 2018). These simultaneously working removal mechanisms allow the treatment of water streams with a wide variety of contaminants. In fact, one of the largest CWs in the world was built in the desert of Oman for the treatment of PI-WW (Stefanakis et al. 2018). The treatment of PI-WW in CWs results in the removal of heavy oil fractions and grease compounds (Abed et al. 2014; Alley et al. 2013; Horner et al. 2012; Ji et al. 2002, 2007; Stefanakis 2018a, b), light hydrocarbons (Stefanakis 2020b), heavy metals (Alley et al. 2013; Horner et al. 2012; Ji et al. 2002, 2007; Kanagy et al. 2008), organics (Ji et al. 2002, 2007; Stefanakis 2018, 2019; Rehman et al. 2019) and total nitrogen (Ji et al. 2002, 2007, Stefanakis 2018, 2019) from the PI-WW with a low salinity. The removal of conditioning chemicals from PI-WW in CWs has not been assessed yet. In addition, it is not known what the effect of increasing salinities of PI-WW on the treatment efficiency of the $\mathrm{CW}$ is. The salinity of PI-WWs ranges worldwide from 1 to $300 \mathrm{~g} / \mathrm{L}$ and is the result of both subsurface geochemical conditions and the injection of oil recovery fluids (Rosenblum et al. 2017; Al-Ghouti et al. 2019). Although the PI-WW does show temporal changes in composition and salinity (Rosenblum et al. 2017), the dominant ions in PI-WW are generally sodium and chloride (Fakhru'lRazi et al. 2009). The salinity determines the viability of plants in the CW (Klomjek and Nitisoravut 2005) and influences removal mechanisms, such as biodegradation and adsorption (Wagner et al. 2018). Furthermore, the salinity of the CW effluent will determine the options for reuse of the treated PI-WW.

In the present study, synthetic PI-WW with light hydrocarbons and increasing salinities was treated in lab-scale verticalflow CWs planted with Phragmites australis or Typha latifolia under hot arid conditions to assess the effect of an increasing salinity on the viability of $P$. australis and $T$. latifolia. In addition, we determined the impact of an increasing salinity on the removal of a heavy metal (zinc), a conditioning chemical (benzotriazole) and an aromatic hydrocarbon (benzoic acid) from synthetic PI-WW, and the contribution of the plant species to the removal of these pollutants.

\section{Materials and methods}

\section{Chemicals}

Calcium chloride dihydrate $\left(\mathrm{CaCl}_{2} \cdot 2 \mathrm{H}_{2} \mathrm{O}\right)$, di-potassium hydrogen phosphate trihydrate $\left(\mathrm{K}_{2} \mathrm{HPO}_{4} \cdot 3 \mathrm{H}_{2} \mathrm{O}\right)$, magnesium sulphate heptahydrate $\left(\mathrm{MgSO}_{4} \cdot 7 \mathrm{H}_{2} \mathrm{O}\right)$, urea, zinc chloride $\left(\mathrm{ZnCl}_{2}\right)$ and yttrium standard solution $\mathrm{Y}\left(\mathrm{NO}_{3}\right)_{3}$ in $\left.\mathrm{HNO}_{3}, 1000 \mathrm{mg} / \mathrm{L} \mathrm{Y}\right)$ were obtained from Merck KGaA (Darmstadt, Germany). Sodium chloride $(\mathrm{NaCl})$, methanol (LC-grade) and acetic acid (99\%) were obtained from VWR Chemicals (Leuven, Belgium). Benzoic acid and benzotriazole were obtained from Carl Roth GmbH (Karlsruhe, Germany).

Benzotriazole, benzoic acid, urea, $\mathrm{CaCl}_{2} \cdot 2 \mathrm{H}_{2} \mathrm{O}$, $\mathrm{K}_{2} \mathrm{HPO}_{4} \cdot 3 \mathrm{H}_{2} \mathrm{O}, \mathrm{MgSO}_{4} \cdot 7 \mathrm{H}_{2} \mathrm{O}, \mathrm{ZnCl}_{2}$ and $\mathrm{NaCl}$ were used for the production of synthetic PI-WW. Acetic acid, methanol and $\mathrm{Y}\left(\mathrm{NO}_{3}\right)_{3}$ in $\mathrm{HNO}_{3}$ were used for sample preparation and analysis.

\section{Lab-scale constructed wetlands}

Six vertical-flow CWs based on the CWs described by Saha et al. (2020) were built in glass containers of $25 \times 25 \times 25 \mathrm{~cm}$ with dark sides to prevent algae growth. The $\mathrm{CW}$ substrate consisted of 3 layers. The bottom layer contained $4 \mathrm{~cm}$ of 8 $16 \mathrm{~mm}$ gravel (GAMMA, Wageningen, The Netherlands) for optimal water drainage. This was covered with a 16-cm layer of a mixture of $75 \%$ sand with a diameter of $>2 \mathrm{~mm}$ (GAMMA, 
Wageningen, The Netherlands) mixed with $25 \%$ sediment from a fully operational $P$. australis planted surface-flow $\mathrm{CW}$ to inoculate the substrate. This layer was covered with $2 \mathrm{~cm}$ of the 8 $16 \mathrm{~mm}$ gravel for optimal water distribution. Two CWs were planted with $P$. australis, two CWs were planted with $T$. latifolia and two CWs remained unplanted to determine the effect of vegetation on the $\mathrm{CW}$ treatment efficiency. The CWs were placed in a Heraeus Vötsch MC 785-KLIMA climate chamber (Weiss Technik, Stuttgart, Germany) that simulated the climatic circumstances at the Arabic peninsula with a temperature of $30{ }^{\circ} \mathrm{C}$, relative humidity of $57.2 \%$ and a light exposure time of $9.5 \mathrm{~h} /$ day. The $\mathrm{CWs}$ were fed 4 times per day, $45 \mathrm{~min}$ and $0.85 \mathrm{~L}$ per feeding cycle, by a Watson Marlow 205U pump (Rotterdam, The Netherlands), which resulted in a theoretical hydraulic retention time of approximately 1 day. The effluent was collected in 500-mL Schott bottles with a continuous overflow system to the sewer.

\section{Influent composition}

The CWs were fed with a mix of synthetic PI-WW with light hydrocarbons and synthetic domestic wastewater (Table 1). A mixture of synthetic PI-WW with synthetic domestic wastewater was used to simulate mixing of these two water streams at oil extraction facilities, which could supply the plants in the $\mathrm{CW}$ with necessary nutrients. The composition of the synthetic municipal wastewater was based on the guidelines for synthetic wastewater preparation of the OECD test 303A (OECD 2001). In the synthetic PI-WW, benzoic acid was used as a representative aromatic hydrocarbon. Benzotriazole was added as representative conditioning chemical because of its use as corrosion inhibitor in the oil extraction process. Zinc is one of the more common heavy metals in PI-WW and originates partly from the galvanized steel structures used in oil extraction (Lee and Neff 2011). Sodium chloride was used to adjust the salinity of the synthetic wastewater mixture, since these ions are the most common ions in PI-WW (Fakhru'lRazi et al. 2009; Jimenez et al. 2018; Al-Ghouti et al. 2019).

\section{Experimental timeline}

During the first 10 days, the CWs were fed with only synthetic domestic wastewater to start up the microbial activity in the
CWs. After 10 days, the systems were fed with the mixture of synthetic PI-WW and synthetic municipal wastewater with a salinity of $2 \mathrm{~g} / \mathrm{L}$. Sampling started 24 days later. The salinity of the synthetic mix was increased from 2 to 4,8 and $12 \mathrm{~g} / \mathrm{L}$ every 21 days.

\section{Sampling and sample preparation}

Liquid samples were taken twice per week from the influent and effluent of the CWs. Samples for benzotriazole analysis were filtered over a $0.2-\mu \mathrm{m}$ polyethersulfone (PES) filter, diluted $100 \times$ with ultrapure water and stored in $1.5-\mathrm{mL}$ glass LC vials at $-20{ }^{\circ} \mathrm{C}$ until analysis. Samples for benzoic acid analysis were filtered over a $0.2-\mu \mathrm{m}$ PES filter, acidified with $1 \%$ $(\mathrm{v} / \mathrm{v})$ acetic acid $(99 \%)$ and stored in $1.5-\mathrm{mL}$ glass LC vials at $-20{ }^{\circ} \mathrm{C}$ until analysis. Samples for zinc analysis were spiked with $1 \%(\mathrm{v} / \mathrm{v})$ of the yttrium internal standard solution ("Chemicals" section).

\section{Analyses}

The temperature, $\mathrm{pH}$ and electrical conductivity (EC) were measured with a Hach Lange HQ440D multimeter (Tiel, The Netherlands). Benzotriazole was analysed by LC-MS/ MS as described by Wagner et al. (2020a). Benzoic acid was determined by HPLC-DAD as described by Wagner et al. (2020b). Zinc was measured based on a certified ICP method of the Belgian federal agency of food chain security (2017/IMET-209/LAB/FLVVG) using a PerkinElmer Avio 500 ICPOES spectrometer (Groningen, The Netherlands) in axial and radial plasma view mode. The high-energy (f/6.7) echellebased ICP-OES utilized two SCD detectors covering the spectral range from 163 to $782 \mathrm{~nm}$. The injector tube was made of alumina and had an internal diameter of $2 \mathrm{~mm}$. Argon (99.998\%, Linde Gas, The Netherlands) was used as the plas$\mathrm{ma}(10 \mathrm{~L} / \mathrm{min})$, auxiliary $(0.2 \mathrm{~L} / \mathrm{min})$ and nebuliser gas $(0.6 \mathrm{~L} /$ min). Nitrogen (99.996\%, Linde Gas, The Netherlands) was used as purging gas $(2 \mathrm{~L} / \mathrm{min})$ in the optical system of the spectrometer. The ICP-OES was operated with a plasma power of $1300 \mathrm{~W}$, a signal integration time of $5 \mathrm{~s}$, and peak processing in peak area mode, using three points/peak for integration. The analytical wavelength of $\mathrm{Zn}$ (II) was $206.200 \mathrm{~nm}$. The emission line of Y(II)-371.027 was used as an internal
Table 1 Composition of synthetic mix of petroleumindustry wastewater and domestic waste water

\begin{tabular}{llll}
\hline $\begin{array}{l}\text { Synthetic petroleum-industry } \\
\text { wastewater components }\end{array}$ & Concentration & $\begin{array}{l}\text { Synthetic domestic waste } \\
\text { water components }\end{array}$ & Concentration \\
\hline Benzoic acid & $40 \mathrm{mg} / \mathrm{L}$ & Urea & $30 \mathrm{mg} / \mathrm{L}$ \\
Benzotriazole & $1 \mathrm{mg} / \mathrm{L}$ & $\mathrm{K}_{2} \mathrm{HPO}_{4} \cdot 3 \mathrm{H}_{2} \mathrm{O}$ & $28 \mathrm{mg} / \mathrm{L}$ \\
$\mathrm{ZnCl}_{2}$ & $10 \mathrm{mg} / \mathrm{L}$ & $\mathrm{CaCl}_{2} \cdot 2 \mathrm{H}_{2} \mathrm{O}$ & $4 \mathrm{mg} / \mathrm{L}$ \\
$\mathrm{NaCl}$ & $2,4,8,12 \mathrm{mg} / \mathrm{L}$ & $\mathrm{MgSO}_{4} \cdot 7 \mathrm{H}_{2} \mathrm{O}$ & $2 \mathrm{mg} / \mathrm{L}$ \\
\hline
\end{tabular}


standard. Data acquisition and analysis were performed with Syngistix ${ }^{\mathrm{TM}}$ Atomic Spectroscopy Software.

\section{Results and discussion}

\section{The influence of salinity on plant growth}

Typha latifolia and Phragmites australis both grew well at a synthetic PI-WW salinity of $2 \mathrm{~g} / \mathrm{L}$ and a temperature of $30^{\circ} \mathrm{C}$ (Fig. S1), demonstrating that these plant species are suitable choices for CWs treating mildly saline water in hot, arid climates. A picture of the planted and unplanted CWs during the complete experimental period is provided in the supplementary info (SI) (Fig. S1). P. australis survived better with increasing salinities then $T$. latifolia, as shown by visual observations of the plant colour, plant height and plant leaf density. At a salinity of $4 \mathrm{~g} / \mathrm{L}$, the $T$. latifolia started to discolour, while no visual effect of the increased salinity on the $P$. australis was observed (Fig. S1). At a salinity of $8 \mathrm{~g} / \mathrm{L}$, the $T$. latifolia completely discoloured and died, while the growth of the $P$. australis seemed to be impeded and its leaves became a lighter tone of green (Fig. S1). At $12 \mathrm{~g} / \mathrm{L}$, P. australis leaves discoloured and the plant height decreased (Fig. S1).

The impact of the salinity on $P$. australis has already been studied extensively, and $P$. australis is known to tolerate salinity levels below $15 \mathrm{~g} / \mathrm{L}$, with a higher tolerance for rhizome-grown plants, as used in the present study, than for seed-grown plants (Lissner and Schierup 1997). P. australis is relatively tolerant to $\mathrm{NaCl}$ stress because it restricts the transport of $\mathrm{Na}^{+}$and $\mathrm{Cl}^{-}$ions to the leaves, it intrinsically enhances the water use efficiency and it produces proline to adjust the intracellular osmotic pressure (Pagter et al. 2009). A too high salt concentration reduces the biomass of $P$. australis as a result of osmotic and ion-specific effects (Pagter et al. 2009), as was observed at a $\mathrm{NaCl}$ concentration of $12 \mathrm{~g} / \mathrm{L}$ in the present study. The impact of the salinity on plant growth is less extensively studied for $T$. latifolia compared to P. australis. T. latifolia is reported to grow well in CWs treating shrimp farming wastewater with a salinity of 3-8 g/ $\mathrm{L}$, where the T. latifolia overgrew 9 other planted species in the second year of growth (Tilley et al. 2002). In addition, T. latifolia grew well in CWs treating fish farming wastewater with a salinity of $24 \mathrm{~g} / \mathrm{L}$ (Jesus et al. 2014), which contradicts with the complete withering of the $T$. latifolia at a $\mathrm{NaCl}$ concentration of $8 \mathrm{~g} / \mathrm{L}$ in the present study. The difference in salinity tolerance of T. latifolia in the present study and the study of Jesus et al. (2014) can be the result of a difference in origin of the plants, a difference in the climatic circumstances in which the plants were grown, or a different effect of the type of wastewater. Hootsman and Wiegman (1998) observed that T. latifolia died as result of treatment with $18 \mathrm{~g} / \mathrm{L}$ sea salt that mainly contains $\mathrm{NaCl}$, whereas $P$. australis was able to survive. For hot climatic conditions, when living vegetation is required in the $\mathrm{CW}, P$. australis proves to be a better choice as vegetation in CWs treating saline water.

\section{The influence of constructed wetland treatment on the electrical conductivity}

The presence of P. australis and T. latifolia substantially impacted the electrical conductivity (EC) of the effluent of the $\mathrm{CWs}$, as long as the plants were alive (Fig. 1).

A NaCl influent concentration of $2 \mathrm{~g} / \mathrm{L}$ resulted in an $\mathrm{EC}$ of $\sim 3 \mathrm{mS} / \mathrm{cm}$, while a $\mathrm{NaCl}$ influent concentration of $12 \mathrm{~g} / \mathrm{L}$ resulted in an EC of $\sim 17 \mathrm{mS} / \mathrm{cm}$ (Fig. 1), suggesting that $\mathrm{NaCl}$ is the main contributing factor to the EC. The EC of the effluent of the unplanted CWs was slightly higher than the EC of the influent (Fig. 1), most likely due to evaporation of the water as a result of the high temperature. The presence of $P$. australis and $T$. latifolia substantially increased the EC of the treated effluent as a result of plant transpiration (Fig. 1). Combined evaporation and plant transpiration, evapotranspiration, resulted in an effluent EC that was substantially higher than the influent EC during low salt concentrations of $2 \mathrm{~g} / \mathrm{L}$ and $4 \mathrm{~g} / \mathrm{L}$ for both plant species (Fig. 1). The EC of the effluent increased because plants protect their plant tissue against toxic concentrations of mainly $\mathrm{Na}^{+}$and $\mathrm{Cl}^{-}$ions by excluding these when they take up water with their root system (Munns and Tester 2008), leaving these ions in the water that exits the $\mathrm{CW}$ as effluent.

The visual observations of the plant vitality ("The influence of salinity on plant growth" section) are corroborated by the trends of the EC of the effluent of the planted CWs. With a $\mathrm{NaCl}$ concentration of $2 \mathrm{~g} / \mathrm{L}$, the $\mathrm{EC}$ of the effluent of the CWs planted with $P$. australis and $T$. latifolia is similar to each other (Fig. 1), revealing a similar evapotranspiration rate. During the addition of $4 \mathrm{~g} / \mathrm{L} \mathrm{NaCl}$, the $\mathrm{EC}$ of the $P$. australis planted $\mathrm{CW}$ effluent was higher than the EC of the T. latifolia planted $\mathrm{CW}$ effluent. The difference in EC between the two vegetation types further increased when the salt concentrations were increased to $8 \mathrm{~g} / \mathrm{L}$ and $12 \mathrm{~g} / \mathrm{L} \mathrm{NaCl}$, demonstrating a higher evapotranspiration in the $P$. australis planted CWs. During the increase of the $\mathrm{NaCl}$ concentration from 4 to $12 \mathrm{~g} / \mathrm{L}$, the EC of the effluent of the T. latifolia planted CWs approached the EC of the effluent of the unplanted CWs, illustrating that plant transpiration stopped. This is in agreement with visual observations of the T. latifolia death ("The influence of salinity on plant growth" section). The higher EC of the P. australis effluent compared to the unplanted $\mathrm{CWs}$ at $12 \mathrm{~g} / \mathrm{L} \mathrm{NaCl}$ implies that the plant still actively transpires water and is thus functional, despite the (partial) leaf decolouration ("The influence of salinity on plant growth" section). 
Fig. 1 Influent and effluent electrical conductivity over time with increasing $\mathrm{NaCl}$ concentrations

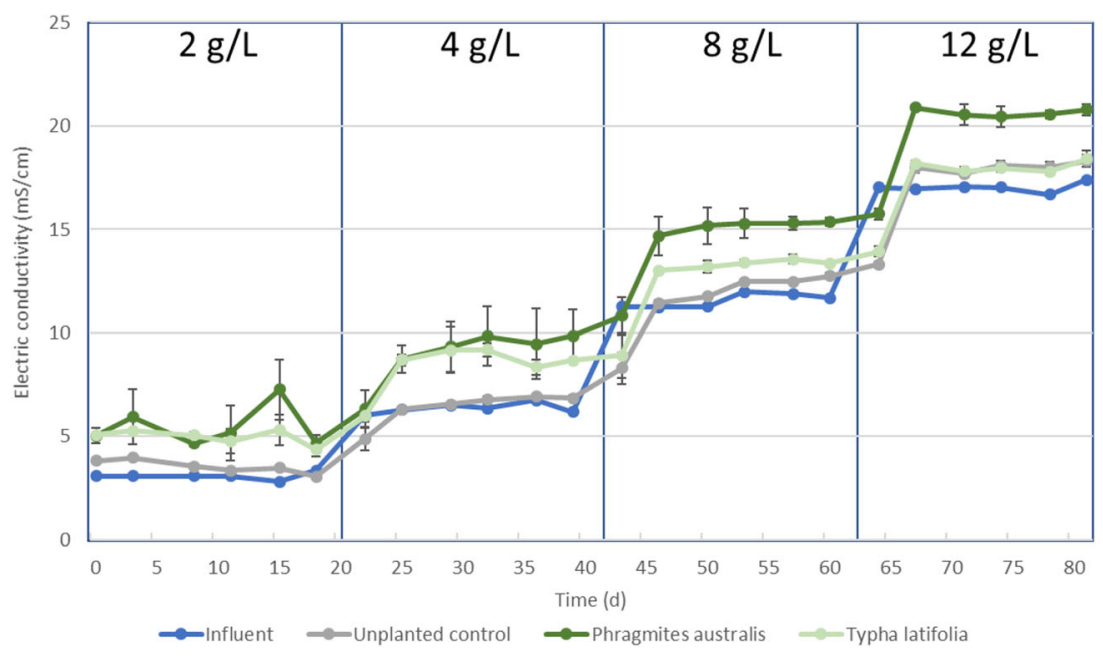

\section{The impact of an increasing salinity on the removal of benzoic acid}

Aromatic hydrocarbon benzoic acid was completely removed in planted $\mathrm{CWs}$ at a $\mathrm{NaCl}$ concentration of $2 \mathrm{~g} / \mathrm{L}$, as demonstrated by the low residual concentrations in the effluent of the CWs compared to the influent concentration (Fig. 2). Complete benzoic acid removal in planted CWs was observed previously (Zachritz et al. 1996; Wagner et al. 2020c) and was the result of biodegradation (Wagner et al. 2020b). Previous studies also showed that biodegradation was the main removal mechanism in subsurface-flow CWs for other aromatic hydrocarbons, such as phenol (Stefanakis et al. 2016). Benzoic acid biodegradation occurs both in aerobic and anaerobic conditions, and many microorganisms, such as Pseudomonas, can degrade benzoic acid (Ziegler et al. 1987; Parsons et al. 1988; Hall et al. 1999). Pseudomonas was also identified by Hashmat et al. (2018) in their surface-flow CWs treating water contaminated with aromatic hydrocarbons. Benzoic acid did not adsorb to CW substrate (Wagner et al. 2020b). Plant uptake of benzoic acid cannot be ruled out in the present study, but the benzoic acid removal efficiency of the unplanted $\mathrm{CWs}$ varied between 70 and $100 \%$ at a $\mathrm{NaCl}$ concentration of $2 \mathrm{~g} / \mathrm{L}$ (Fig. 2), which was solely the result of biodegradation. Hence, biodegradation is the main removal mechanism for benzoic acid in the present study and complete benzoic acid removal in the planted CWs is probably because the presence of vegetation results in a higher microbial density and microbial activity (Gagnon et al. 2007; Zhang et al. 2010; Nguyen et al. 2019), since the plant rhizosphere provides nutrients and favourable redox conditions (Gagnon et al. 2012). In the unplanted CWs, the absence of the vegetation probably results in less favourable conditions for the microorganisms, resulting in a decreased benzoic acid removal efficiency after the first 5 days.

With an increasing $\mathrm{NaCl}$ concentration increasing to $8 \mathrm{~g} / \mathrm{L}$, benzoic acid remains almost completely removed in the planted CWs (Fig. 2). Surprisingly, the removal efficiency in the unplanted CW increased over time (Fig. 2). This could be an indication that the microbial biomass in the newly started
Fig. 2 Influent (blue line) and effluent benzoic acid concentrations over time with increasing $\mathrm{NaCl}$ concentrations in $P$. australis planted CWs (dark green line), Typha latifolia planted CWs (light green line) and unplanted CWs (grey line). The effluent of both the Phragmites australis planted CWs and Typha latifolia planted $\mathrm{CWs}$ were 0 during the first 25 days and thus overlap

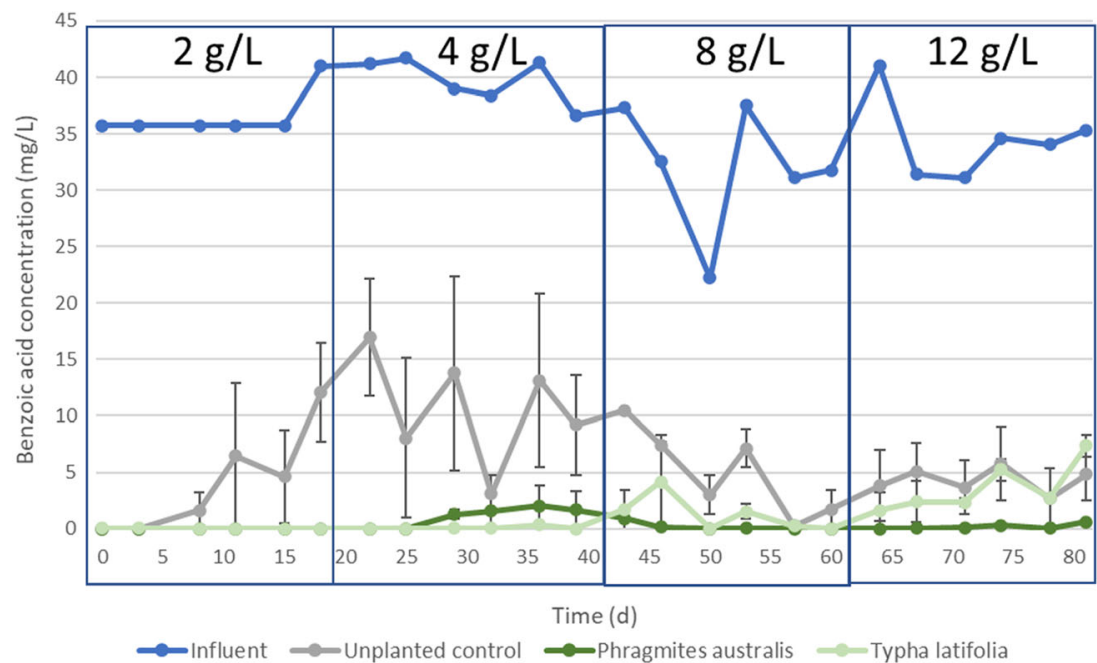


CWs increased despite the increasing $\mathrm{NaCl}$ concentrations, resulting in a higher benzoic acid removal efficiency. An increasing biodegradation efficiency with increased salinities is in contrast with Lin et al. (2008) and Villasenor Camacho et al. (2017), who observed decreasing biodegradation efficiencies in CWs fed with influent with increasing salinities. At a $\mathrm{NaCl}$ concentration of $12 \mathrm{~g} / \mathrm{L}$, the residual benzoic acid concentration in the effluent of the unplanted CWs stabilized at around $5 \mathrm{mg} / \mathrm{L}$. The benzoic acid is still completely removed in the $P$. australis planted CWs (Fig. 2). In contrast, at this $\mathrm{NaCl}$ concentration, the benzoic acid concentration in the effluent of the T. latifolia planted CWs became similar to the effluent concentration of the unplanted CWs (Fig. 2). We hypothesize that the microbial community in this $\mathrm{CW}$ was less well able to cope with the increased $\mathrm{NaCl}$ concentration, as a result of the loss of its favourable environment due to the death of the T. latifolia ("The influence of salinity on plant growth" section). In the present study, a cutoff point for benzoic acid biodegradation was not observed for $\mathrm{NaCl}$ concentrations up to $12 \mathrm{~g} / \mathrm{L}$. Castillo-Carvajal et al. (2014) showed that aromatic hydrocarbons can be biodegraded by halophilic bacteria up to a NaCL concentration of $200 \mathrm{~g} / \mathrm{L}$.

\section{The impact of an increasing salinity on the removal of benzotriazole}

The removal efficiency of the unplanted, $P$. australis planted and T. latifolia planted CWs for conditioning chemical benzotriazole differed substantially at a $\mathrm{NaCl}$ concentration of $2 \mathrm{~g} / \mathrm{L}$ (Fig. 3).

The lowest benzotriazole removal efficiency at a $\mathrm{NaCl}$ concentration of $2 \mathrm{~g} / \mathrm{L}$ was observed in the unplanted CWs (Fig. 3). The removal of benzotriazole in CWs is the result of simultaneous adsorption to the substrate and aerobic biodegradation, as demonstrated before (Wagner et al. 2020a). The presence of plants in the present study enhanced the benzotriazole removal efficiency, and the CWs planted with $P$. australis had a higher removal efficiency than the $T$. latifolia planted CWs (Fig. 3). The uptake and transformation of benzotriazole in the plants was not studied; hence, it is not possible to distinguish between direct enhancement as a result of plant uptake and degradation in the plant tissue and an indirect enhancement as a result of a more favourable environment by microorganisms in the plant rhizosphere. However, the uptake and degradation of benzotriazole by plants in CWs has been described for other plant species than those used in the present study, such as Arabidopsis thaliana and Carex praegracilis (LeFevre et al. 2015; Pritchard et al. 2018). The benzotriazole removal efficiency at a mild salinity of $2 \mathrm{~g} / \mathrm{L}$ under hot arid circumstances in the $P$. australis planted verticalflow CWs (Fig. 3) was comparable with the benzotriazole removal efficiency ranging from 63 to $90 \%$ in vertical-flow CWs treating domestic wastewater or cooling tower water in less hot climates as observed by others (Matamoros et al. 2010; Kahl et al. 2017; Brunsch et al. 2018; Nivala et al. 2019; Brunsch et al. 2020; Wagner et al. 2020a).

Increasing $\mathrm{NaCl}$ concentrations from 2 to $12 \mathrm{~g} / \mathrm{L}$ lowered the benzotriazole removal efficiency in the planted and unplanted CWs (Fig. 3). However, despite the high evapotranspiration and corresponding concentration increase of both $\mathrm{NaCl}$ and fractions that are not taken up by the plants, there is still a net removal of benzotriazole over the whole experimental period for the planted and unplanted CWs (Fig. 3). The increasing difference between the $P$. australis planted CWs and T. latifolia planted CWs indicates that the death of the T. latifolia ("The influence of salinity on plant growth" section) is responsible for the large decrease in benzotriazole removal efficiency in the T. latifolia planted CWs. At a salinity of $12 \mathrm{~g} / \mathrm{L}$, the removal efficiency of the unplanted and T. latifolia planted $\mathrm{CW}$ was similar, indicating the
Fig. 3 Influent (blue line) and effluent benzotriazole concentrations over time with increasing $\mathrm{NaCl}$ concentrations in $P$. australis planted CWs (dark green line), Typha latifolia planted CWs (light green line) and unplanted CWs (grey line)

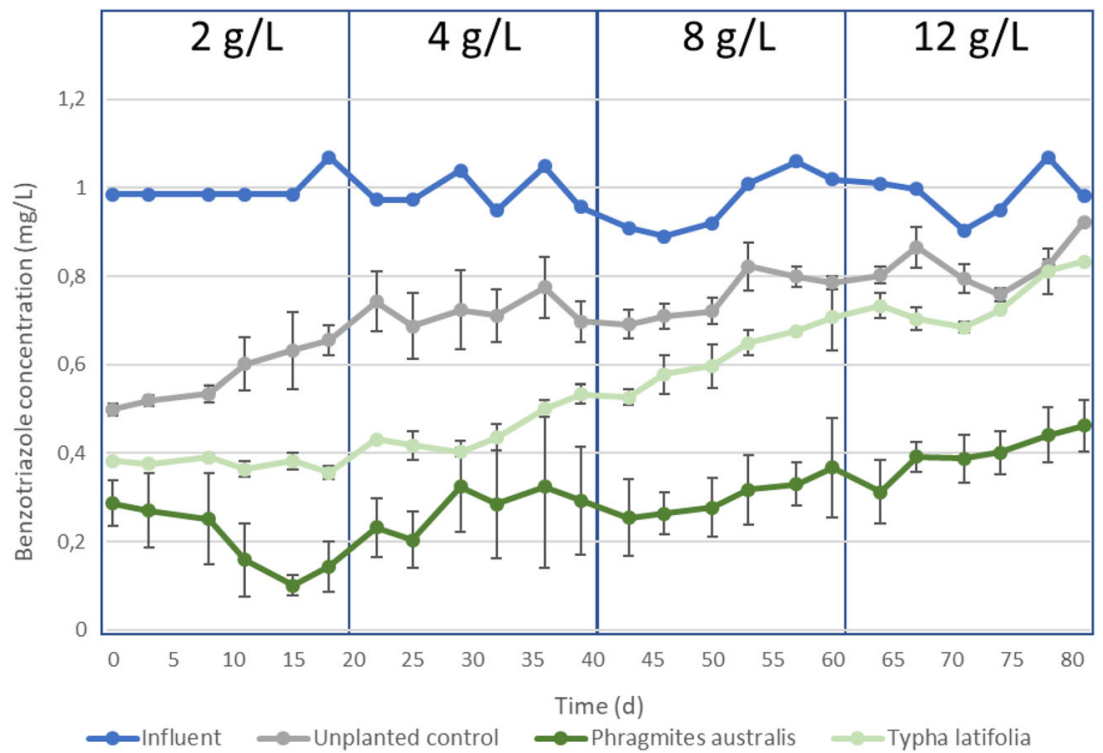


absence of a positive effect of the vegetation on the benzotriazole removal in these CWs. In the P. australis planted CWs, the benzotriazole removal efficiency at a $\mathrm{NaCl}$ concentration of $12 \mathrm{~g} / \mathrm{L}$ was slightly lower than at $2 \mathrm{~g} / \mathrm{L}$, but still showed more than $50 \%$ removal (Fig. 3). Given the benzotriazole removal efficiency difference between the $P$. australis and T. latifolia planted CWs, this is the result of biological removal with $P$. australis, and $P$. australis is still capable of stimulating the biological benzotriazole removal at a $\mathrm{NaCl}$ concentration of $12 \mathrm{~g} / \mathrm{L}$, despite the first signs of plant discolouration ("The influence of salinity on plant growth" section).

\section{The impact of an increasing salinity on the removal of zinc}

The removal of zinc is substantially impacted by an increase in the $\mathrm{NaCl}$ concentration in the T. latifolia and $P$. australis planted CWs (Fig. 4). In the unplanted CWs, the effluent concentrations of zinc are not affected by increasing $\mathrm{NaCl}$ concentrations, and approximately $80 \%$ of the zinc is removed (Fig. 4).

At a $\mathrm{NaCl}$ concentration of $2 \mathrm{~g} / \mathrm{L}$, the $P$. australis and T. latifolia planted CWs have similar effluent zinc concentrations that are higher than those of the unplanted CW (Fig. 4), with substantial deviations in the removal efficiencies of the experimental duplicates of mainly the $P$. australis planted CWs. Evapotranspiration resulted in a higher concentration of zinc in the effluent of the planted CWs, but the evapotranspiration rate cannot fully explain the difference in zinc removal between the planted and unplanted CWs. In addition, the deviation in effluent zinc concentration of the $P$. australis duplicates are not the result of differences in evapotranspiration, since the deviation of the effluent $\mathrm{EC}$ in the planted $\mathrm{CWs}$ is smaller than the deviation in effluent zinc concentrations (Figs. 1 and 4). The differences in removal efficiency of the planted CWs could be the result of difference in root system development. The removal of zinc in CWs is the result of precipitation in the rhizosphere and on the root surface of wetland plants (Otte et al. 1995) and uptake by the plants (Sheoran and Sheoran 2006). In addition, zinc adsorbs to the $\mathrm{CW}$ substrate as result of cation exchange or chemisorption and to clay and organic matter by electrostatic interaction (Sheoran and Sheoran 2006). The lower removal in the planted CWs is probably governed by a rhizospheric decrease of the $\mathrm{pH}$ and higher redox conditions by oxygen influx through plants in the planted CWs. The differences in development of the rhizosphere might explain the differences between experimental duplicates. The rhizosphere is able to decrease the $\mathrm{pH}$ within $1 \mathrm{~cm}$ of the root system by the release of acidic root exudates, and this decreased $\mathrm{pH}$ causes changes in metal speciation and solubility (Weis and Weis 2004), and competition for adsorption on the $\mathrm{CW}$ matrix between the proton and metal cations. Moreover, oxygen influx through the plant root system might mitigate the establishment of sulphate-reducing conditions in planted systems, which prevents zinc-sulphide precipitation and keeps the $\mathrm{Zn}$ ions in solution. Wright and Otte (1999) showed that a decreased $\mathrm{pH}$ in the rhizospere increased the concentrations of dissolved zinc near the roots of $T$. latifolia, and the transport of this dissolved zinc to the effluent would result in a lower zinc removal efficiency in the planted CWs. This suggests that more detailed probing of $\mathrm{pH}$, redox and dissolved $\mathrm{Zn}$ gradients in the root zones of the $\mathrm{CW}$ could shed more light on the actual mechanisms controlling zinc adsorption and desorption in CWs, for which the experimental setup of the present study did not allow for.

An increase in the $\mathrm{NaCl}$ concentration from 2 to $4 \mathrm{~g} / \mathrm{L}$ resulted in a sudden increase in the effluent zinc concentration of the T. latifolia and P. australis planted CWs to a concentration above the influent concentration of approximately $5 \mathrm{mg} / \mathrm{L}$ (Fig. 4). After this increase, the effluent concentration
Fig. 4 Influent (blue line) and effluent zinc concentrations over time with increasing $\mathrm{NaCl}$ concentrations in P. australis planted CWs (dark green line), Typha latifolia planted CWs (light green line) and unplanted CWs (grey line)

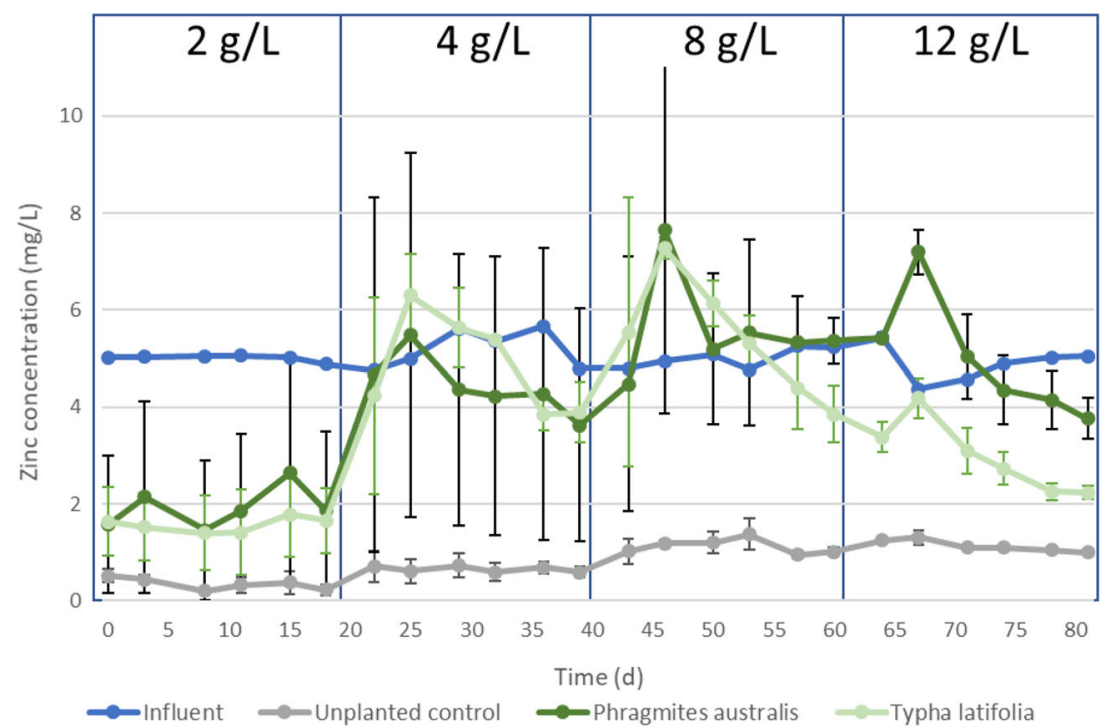


stabilized around $4 \mathrm{mg} / \mathrm{L}$, and never reached the effluent concentration at a $\mathrm{NaCl}$ concentration of $2 \mathrm{~g} / \mathrm{L}$. A similar increase in effluent zinc concentration was observed with an increase of the $\mathrm{NaCl}$ concentration from 4 to $8 / \mathrm{L}$. Such increased effluent zinc concentrations were not observed in the unplanted CWs, indicating that plant-mediated processes are responsible for the observed increased zinc concentrations. The release of zinc from the planted CWs after an increase in the salinity could be the result of the complexation of zinc with root exudates that are released to protect the plant against the increased $\mathrm{NaCl}$ concentrations and that increase the zinc mobility (Lutts and Lefèvre 2015). The low increase in the effluent zinc concentration of the $T$. latifolia planted CWs with an increase in $\mathrm{NaCl}$ concentration from 8 to $12 \mathrm{~g} / \mathrm{L}$, where the T. latifolia died ("The influence of salinity on plant growth" section), provides additional proof that the release of $\mathrm{Zn}$ at salinity increases at lower salinities is a result of an active plant response mechanisms to increased salinities.

\section{Reuse of petroleum-industry wastewater in hot arid climates}

It can be concluded from the present study that treatment of synthetic mildly saline PI-WW with a $\mathrm{NaCl}$ concentration up to $12 \mathrm{~g} / \mathrm{L}$ in $\mathrm{CWs}$ in simulated hot arid climatic conditions results in the removal of the conditioning chemicals benzotriazole and aromatic hydrocarbon benzoic acid from the synthetic PI-WW. However, the present study also shows that increasing salt concentrations of the $\mathrm{CW}$-influent negatively affect the biodegradation of benzotriazole and benzoic acid. Increasing salt concentrations also affect the removal of zinc from the synthetic PI-WW. Zinc is steadily removed from the synthetic saline PI-WW as long as the salinity of the influent is stable, but fluctuating salt concentrations result in spikes of the effluent zinc concentration as result of active plant defence mechanisms. Moreover, evaporation and evapotranspiration in the hot and arid conditions applied in the present study result in an increased $\mathrm{EC}$ of the $\mathrm{CW}$ treated water.

The increased $\mathrm{EC}$ of the $\mathrm{CW}$ effluent limits its further reuse options. Al-Ghouti et al. (2019) identified various reuse options for PI-WW: livestock watering, habitat and wildlife watering, fire control, dust control, reuse in the oilfield, cooling water during power generation and irrigation in agriculture. A distinction is made between irrigation of food crops and irrigation of non-food crops that can be used for instance as bio-based fuels or construction material. For non-food crops, the legislative water quality requirements are generally lower (Al-Ghouti et al. 2019). Plant growth can be substantially hindered by too high salt concentrations of the treated PI-WW (Pica et al. 2017). The use of treated saline PI-WW can not only negatively affect the growth of plants directly but can also result in an increased soil salinity and soil sodicity (Echchelh et al. 2018). These processes can irreversibly change the soil structure and significantly lower the soil fertility (Echchelh et al. 2018). Therefore, various countries have guidelines in place with threshold values for the EC, sodium adsorption ratio (SAR) and heavy metal concentrations to which irrigation water has to comply to prevent damage to soil and crops (do Monte 2007; Jeong et al. 2016).

An increased salinity as result of CW treatment does not only limit the applicability of PI-WW for irrigation in many countries, but also its use in industrial processes, such as its use as cooling tower make-up water (Wagner et al. 2018). To make the treated PI-WW suitable for either irrigation or as make-up water, CW treatment can be followed by desalination technologies to obtain appropriate salinities for reuse. Desalination of PI-WW has been studied extensively (Al-Ghouti et al. 2019; Fakhru'lRazi et al. 2009; Shaffer et al. 2013), and various technologies are capable to lower the salinity of PI-WW to a level suitable for use as irrigation water or in cooling towers. For instance, Mallants et al. (2017) showed that reverse osmosis of PI-WW results in a water source that meets the EC requirements for use as irrigation water. CWs can be applied as a pre-treatment before membrane-based desalination of PI-WW to remove fractions that shorten the lifespan of desalination membranes, such as suspended solids and conditioning chemicals (Wagner et al. 2020c). In conclusion, $P$. australis planted CWs are a suitable option for the treatment of water with a salinity below $12 \mathrm{~g} / \mathrm{L}$, and the $\mathrm{CW}$ effluent can be reused directly or further desalinated to increase its reuse options. CW treatment and water reuse would be beneficial not only in water-scarce areas but also in areas with stringent PI-WW discharge regulations. Such CWs will not only protect the environment but can also boost the local biodiversity. Practical implementation of CWs for the treatment of high-volume industrial wastewater, such as PI-WW, is described by Stefanakis (2019).

Acknowledgements The authors acknowledge Rick Helmus, Pieter Gremmen, Jill Soedarso and Bert Willemsen for their technical support.

Availability of data and materials The datasets used and/or analysed during the current study are available from the corresponding author on reasonable request.

Author contributions Conceptualization: Thomas Wagner, Alette Langenhoff, John Parsons, Huub Rijnaarts, Vinnie de Wilde, Koen Wetser, Fatma al-Manji, Jie Xue. Data curation: Thomas Wagner. Formal analysis: Thomas Wagner, Fatma al-Manji, Jie Xue. Funding acquisition: Huub Rijnaarts, Alette Langenhoff, John Parsons. Investigation: Fatma al-Manji, Jie Xue, Thomas Wagner, Koen Wetser, Vinnie de Wilde. Methodology: Thomas Wagner, Vinnie de Wilde, Koen Wetser, Fatma al-Manji, Jie Xue. Project administration: Thomas Wagner. Resources: Vinnie de Wilde. Software: -. Supervision: Thomas Wagner, Alette Langenhoff, John Parsons, Huub Rijnaarts. Validation: Thomas Wagner. Visualization: Thomas Wagner. Writing-original draft: Thomas Wagner. Writing - review and editing: Fatma al-Manji, Jie Xue, Koen Wetser, John Parsons, Huub Rijnaarts, Alette Langenhoff.

Funding This research is financed by the Netherlands Organization for Scientific Research (NWO), which is partly funded by the Ministry of 
Economic Affairs, and co-financed by the Netherlands Ministry of Infrastructure and Environment and partners of the Dutch Water Nexus consortium (Project nr. STW 14302 Water Nexus 3).

\section{Compliance with ethical standards}

Competing interests The authors declare that they have no competing interests.

\section{Ethics approval and consent to participate Not applicable.}

\section{Consent for publication Not applicable}

Open Access This article is licensed under a Creative Commons Attribution 4.0 International License, which permits use, sharing, adaptation, distribution and reproduction in any medium or format, as long as you give appropriate credit to the original author(s) and the source, provide a link to the Creative Commons licence, and indicate if changes were made. The images or other third party material in this article are included in the article's Creative Commons licence, unless indicated otherwise in a credit line to the material. If material is not included in the article's Creative Commons licence and your intended use is not permitted by statutory regulation or exceeds the permitted use, you will need to obtain permission directly from the copyright holder. To view a copy of this licence, visit http://creativecommons.org/licenses/by/4.0/.

\section{References}

Abed RM, Al-Kharusi S, Prigent S, Headley T (2014) Diversity, distribution and hydrocarbon biodegradation capabilities of microbial communities in oil-contaminated cyanobacterial mats from a constructed wetland. PLoS One 9(12):e114570

Afzal M, Rehman K, Shabir G, Tahseen R, Ijaz A, Hashmat AJ, Brix H (2019) Large-scale remediation of oil-contaminated water using floating treatment wetlands. NPJ Clean Water 2:1

Al-Ghouti MA, Al-Kaabi MA, Ashfaq MY, Da'na DA (2019) Produced water characteristics, treatment and reuse: a review. J Water Process Eng 28:222-239

Alley BL, Willis B, Rodgers J Jr, Castle JW (2013) Water depths and treatment performance of pilot-scale free water surface constructed wetland treatment systems for simulated fresh oilfield produced water. Ecol Eng 61:190-199

Brunsch AF, ter Laak TL, Christoffels E, Rijnaarts HH, Langenhoff AA (2018) Retention soil filter as post-treatment step to remove micropollutants from sewage treatment plant effluent. Sci Total Environ 637:1098-1107

Brunsch AF, Florez PZ, Langenhoff AA, ter Laak TL, Rijnaarts HH (2020) Retention soil filters for the treatment of sewage treatment plant effluent and combined sewer overflow. Sci Total Environ 699:134426

Castillo-Carvajal L, Sanz-Martin J, Barragan-Huerta BE (2014) Biodegradation of organic pollutants in saline wastewater by halophilic microorganisms: a review. Environ Sci Pollut Res 21:9578-9588

do Monte MHFM (2007) Wastewater reuse-risk assessment, decisionmaking and environmental security. Springer, pp 253-265

Echchelh A, Hess T, Sakrabani R (2018) Reusing oil and gas produced water for irrigation of food crops in drylands. Agric Water Manag 206:124-134

Fakhru'l-Razi A, Pendashteh A, Abdullah LC, Biak DRA, Madaeni SS, Abidin ZZ (2009) Review of technologies for oil and gas produced water treatment. J Hazard Mater 170(2-3):530-551
Gagnon V, Chazarenc F, Comeau Y, Brisson J (2007) Influence of macrophyte species on microbial density and activity in constructed wetlands. Water Sci Technol 56(3):249-254

Gagnon V, Chazarenc F, Kõiv M, Brisson J (2012) Effect of plant species on water quality at the outlet of a sludge treatment wetland. Water Res 46(16):5305-5315

Garcia J, Rousseau DP, Morato J, Lesage E, Matamoros V, Bayona JM (2010) Contaminant removal processes in subsurface-flow constructed wetlands: a review. Crit Rev Environ Sci Technol 40(7):561-661

Hall JA, Kalin RM, Larkin MJ, Allen CCR, Harper DB (1999) Variation in stable carbon isotope fractionation during aerobic degradation of phenol and benzoate by contaminant degrading bacteria Organic Geochemistry 30:801-811

Hashmat AJ, Afzal M, Fatima K, Anwar-ul-Haq M, Khan QM, Arias CA, Brix H (2018) Characterization of hydrocarbon-degrading bacteria in constructed wetland microcosms used to treat crude oil polluted water. Bull Environ Contam Toxicol 102:358-364

Hootsmans MJ, Wiegman F (1998) Four helophyte species growing under salt stress: their salt of life? Aquatic Botany 62(2):81-94

Horner JE, Castle JW, Rodgers JH, Gulde CM, Myers JE (2012) Design and performance of pilot-scale constructed wetland treatment systems for treating oilfield produced water from sub-Saharan Africa. Water Air Soil Pollut 223(5):1945-1957

Jeong H, Kim H, Jang T (2016) Irrigation water quality standards for indirect wastewater reuse in agriculture: a contribution toward sustainable wastewater reuse in South Korea. Water 8(4):169

Jesus J, Calheiros CS, Castro PM, Borges M (2014) Feasibility of Typha latifolia for high salinity effluent treatment in constructed wetlands for integration in resource management systems. Int J Phytoremediat 16(4):334-346

Ji G, Sun T, Zhou Q, Sui X, Chang S, Li P (2002) Constructed subsurface flow wetland for treating heavy oil-produced water of the Liaohe Oilfield in China. Ecol Eng 18(4):459-465

Ji G, Sun T, Ni J (2007) Surface flow constructed wetland for heavy oilproduced water treatment. Bioresour Technol 98(2):436-441

Jimenez S, Mico MM, Arnaldos M, Medina F, Contreras S (2018) State of the art of produced water treatment. Chemosphere 192:186-208

Kahl S, Nivala J, van Afferden M, Müller RA, Reemtsma T (2017) Effect of design and operational conditions on the performance of subsurface flow treatment wetlands: emerging organic contaminants as indicators. Water Res 125:490-500

Kanagy LE, Johnson BM, Castle JW, Rodgers JH Jr (2008) Design and performance of a pilot-scale constructed wetland treatment system for natural gas storage produced water. Bioresour Technol 99(6): $1877-1885$

Klomjek P, Nitisoravut S (2005) Constructed treatment wetland: a study of eight plant species under saline conditions. Chemosphere 58(5): 585-593

Lee K, Neff J (2011) Produced water: environmental risks and advances in mitigation technologies. Springer

LeFevre GH, Müller CE, Li RJ, Luthy RG, Sattely ES (2015) Rapid phytotransformation of benzotriazole generates synthetic tryptophan and auxin analogs in Arabidopsis. Environ Sci Technol 49(18): 10959-10968

Lin T, Wen Y, Jiang L, Li J, Yang S, Zhou Q (2008) Study of atrazine degradation in subsurface flow constructed wetland under different salinity. Chemosphere 72:122-128

Lissner J, Schierup H-H (1997) Effects of salinity on the growth of Phragmites australis. Aquat Bot 55(4):247-260

Lutts S, Lefèvre I (2015) How can we take advantage of halophyte properties to cope with heavy metal toxicity in salt-affected areas? Ann Bot 115(3):509-528

Mallants D, Šimůnek J, Torkzaban S (2017) Determining water quality requirements of coal seam gas produced water for sustainable irrigation. Agric Water Manag 189:52-69 
Matamoros V, Jover E, Bayona JM (2010) Occurrence and fate of benzothiazoles and benzotriazoles in constructed wetlands. Water Sci Technol 61(1):191-198

Munns R, Tester M (2008) Mechanisms of salinity tolerance. Annu Rev Plant Biol 59:651-681

Murray-Gulde C, Heatley JE, Karanfil T, Rodgers JH Jr, Myers JE (2003) Performance of a hybrid reverse osmosis-constructed wetland treatment system for brackish oil field produced water. Water Res 37(3):705-713

Nguyen PM, Afzal M, Ullah I, Shahid N, Baqar M, Arslan M (2019) Removal of pharmaceuticals and personal care products using constructed wetlands: effective plant-bacteria synergism may enhance degradation efficiency. Environ Sci Pollut Res 26:21109-21126

Nivala J, Kahl S, Boog J, van Afferden M, Reemtsma T, Müller RA (2019) Dynamics of emerging organic contaminant removal in conventional and intensified subsurface flow treatment wetlands. Sci Total Environ 649:1144-1156

OECD (2001) OECD (2001), Test No. 303: simulation test - aerobic sewage treatment - A: activated sludge units; B: biofilms, OECD Guidelines for the Testing of Chemicals, Section 3. OECD Publishing, Paris

Otte M, Kearns C, Doyle M (1995) Accumulation of arsenic and zinc in the rhizosphere of wetland plants. Bull Environ Contam Toxicol 55(1):154-161

Ozgun H, Ersahin ME, Erdem S, Atay B, Sayili S, Eren E, Hoshan P, Atay D, Altinbas M, Kinaci C (2013) Comparative evaluation for characterization of produced water generated from oil, gas, and oilgas production fields. CLEAN-Soil Air Water 41(12):1175-1182

Pagter M, Bragato C, Malagoli M, Brix H (2009) Osmotic and ionic effects of $\mathrm{NaCl}$ and $\mathrm{Na} 2 \mathrm{SO} 4$ salinity on Phragmites australis. Aquat Bot 90(1):43-51

Parsons JR, Sijm DTHM, van Laar A, Hutzinger O (1988) Biodegradation of chlorinated biphenyls and benzoic acids by a Pseudomonas strain. Appl Microbiol Biotechnol 29:81-84

Pica NE, Carlson K, Steiner JJ, Waskom R (2017) Produced water reuse for irrigation of non-food biofuel crops: effects on switchgrass and rapeseed germination, physiology and biomass yield. Ind Crop Prod 100:65-76

Pritchard J, Cho Y-M, Ashoori N, Wolfand J, Sutton J, Carolan M, Gamez E, Doan K, Wiley J, Luthy R (2018) Benzotriazole uptake and removal in vegetated biofilter mesocosms planted with Carex praegracilis. Water 10(11):1605

Rehman K, Imran A, Amin I, Afzal M (2018) Inoculation with bacteria in floating treatment wetlands positively modulates the phytoremediation of oil field wastewater. J Hazard Mater 349:242-251

Rehman K, Imran A, Amin I, Afzal M (2019) Enhancement of oil fieldproduced wastewater remediation by bacterially-augmented floating treatment wetlands. Chemosphere 217:576-583

Rosenblum J, Nelson AW, Ruyle B, Schultz MK, Ryan JN, Linden KG (2017) Temporal characterization of flowback and produced water quality from a hydraulically fractured oil and gas well. Sci Total Environ 596-597:369-377

Saha P, Wagner TV, Ni J, Langenhoff AAM, Bruning H, Rijnaarts HHM (2020) Cooling tower water treatment using a combination of electrochemical oxidation and constructed wetlands. Process Saf Environ Prot 144:42-51

Shaffer DL, Arias Chavez LH, Ben-Sasson M, Romero-Vargas Castrillón S, Yip NY, Elimelech M (2013) Desalination and reuse of highsalinity shale gas produced water: drivers, technologies, and future directions. Environ Sci Technol 47(17):9569-9583

Sheoran A, Sheoran V (2006) Heavy metal removal mechanism of acid mine drainage in wetlands: a critical review. Miner Eng 19(2):105-116

Sosa-Fernandez P, Post J, Bruning H, Leermakers F, Rijnaarts H (2018) Electrodialysis-based desalination and reuse of sea and brackish polymer-flooding produced water. Desalination 447:120-132

Sosa-Fernandez P, Post J, Leermakers F, Rijnaarts H, Bruning H (2019) Removal of divalent ions from viscous polymer-flooding produced water and seawater via electrodialysis. J Membr Sci 589:117251
Stefanakis AI (2018) Constructed wetlands for industrial wastewater treatment. John Wiley \& Sons Ltd, Chichester

Stefanakis AI (2019) Constructed wetlands case studies for the treatment of water polluted with fuel and oil hydrocarbons. In: Ansari AA, Gill SS, Gill R, Lanza G, Newman L (eds) Phytoremediation Management of Environmental Contaminants Vol. 6. Springer International Publishing, Switzerland, pp 151-167

Stefanakis AI (2020a) Constructed wetlands for sustainable wastewater treatment in hot and arid climates: opportunities, challenges and case studies in the Middle East. Water 12

Stefanakis AI (2020b) The fate of MTBE and BTEX in constructed wetlands. Applied Sciences 10

Stefanakis AI, Seeger E, Dorer C, Sinke A, Thullner M (2016) Performance of pilot-scale horizontal subsurface flow constructed wetlands treating groundwater contaminated with phenols and petroleum derivatives. Ecol Eng 95:514-526

Stefanakis AI, Prigent S, Breuer R (2018) Integrated produced water management in a desert oilfield using wetland technology and innovative reuse practices. Constructed Wetlands for Industrial Wastewater Treatment; Stefanakis, AI, Ed.; John Wiley \& Sons Ltd.: Chichester, UK, 25-42

Sudmalis D, Da Silva P, Temmink H, Bijmans M, Pereira M (2018) Biological treatment of produced water coupled with recovery of neutral lipids. Water Res 147:33-42

Tilley DR, Badrinarayanan H, Rosati R, Son J (2002) Constructed wetlands as recirculation filters in large-scale shrimp aquaculture. Aquac Eng 26(2):81-109

Villasenor Camacho J, Rodriguez Romero L, Fernandez Marchante CM, Fernandez Morales FJ, Rodrigo Rodrigo MA (2017) The salinity effects on the performance of a constructed wetland-microbial fuel cell. Ecol Eng 107:1-7

Wagner TV, Parsons JR, Rijnaarts HH, de Voogt P, Langenhoff AA (2018) A review on the removal of conditioning chemicals from cooling tower water in constructed wetlands. Crit Rev Environ Sci Technol 48(19-21):1094-1125

Wagner TV, Parsons JR, Rijnaarts HH, de Voogt P, Langenhoff AA (2020a) Benzotriazole removal mechanisms in pilot-scale constructed wetlands treating cooling tower water. J Hazard Mater 384:121314

Wagner TV, Helmus R, Tapia SQ, Rijnaarts HH, de Voogt P, Langenhoff AA, Parsons JR (2020b) Non-target screening reveals the mechanisms responsible for the antagonistic inhibiting effect of the biocides DBNPA and glutaraldehyde on benzoic acid biodegradation. J Hazard Mater 386:121661

Wagner TV, de Wilde V, Willemsen B, Mutaqin M, Putri G, Opdam J, Parsons JR, Rijnaarts HHM, de Voogt P, Langenhoff AAM (2020c) Pilot-scale hybrid constructed wetlands for the treatment of cooling tower water prior to its desalination and reuse. J Environ Manag 271:110972

Weis JS, Weis P (2004) Metal uptake, transport and release by wetland plants: implications for phytoremediation and restoration. Environ Int 30(5):685-700

Wright DJ, Otte ML (1999) Wetland plant effects on the biogeochemistry of metals beyond the rhizosphere. JSTOR, pp 3-10

Zachritz WH, Lundie LL, Wang H (1996) Benzoic acid degradation by small, pilot-scale artificial wetlands filter (AWF) systems. Ecol Eng 7(2):105-116

Zhang C-B, Wang J, Liu W-L, Zhu S-X, Ge H-L, Chang SX, Chang J, Ge Y (2010) Effects of plant diversity on microbial biomass and community metabolic profiles in a full-scale constructed wetland. Ecol Eng 36(1):62-68

Ziegler K, Braun K, Bockler A, Fuchs G (1987) Studies on the anaerobic degradation of benzoic acid and 2-aminobenzoic acid by a denitrifying Pseudomonas strain. Arch Microbiol 149:62-69

Publisher's note Springer Nature remains neutral with regard to jurisdictional claims in published maps and institutional affiliations. 